\title{
L'épopée médiévale et la Bourgogne (sous la dir. de Muriel Ott)
}

\section{Maria Colombo Timelli}

\section{(2) OpenEdition}

1 Journals

\section{Édition électronique}

URL : http://journals.openedition.org/studifrancesi/9808

DOI : 10.4000/studifrancesi.9808

ISSN : 2421-5856

Éditeur

Rosenberg \& Sellier

\section{Édition imprimée}

Date de publication : 1 octobre 2007

Pagination : $422-423$

ISSN : 0039-2944

\section{Référence électronique}

Maria Colombo Timelli, «L'épopée médiévale et la Bourgogne (sous la dir. de Muriel Ott) », Studi Francesi [En ligne], 152 (LI | II) | 2007, mis en ligne le 30 novembre 2015, consulté le 09 janvier 2021. URL :

http://journals.openedition.org/studifrancesi/9808 ; DOI : https://doi.org/10.4000/studifrancesi.9808

Ce document a été généré automatiquement le 9 janvier 2021.

\section{(c) (i) (9)}

Studi Francesi è distribuita con Licenza Creative Commons Attribuzione - Non commerciale - Non opere derivate 4.0 Internazionale. 


\title{
L'épopée médiévale et la Bourgogne (sous la dir. de Muriel Ott)
}

\author{
Maria Colombo Timelli
}

\section{RÉFÉRENCE}

L'épopée médiévale et la Bourgogne (sous la dir. de Muriel оTT), Dijon, EUD, 2006.

Trois contributions concernent le $\mathrm{xV}^{\mathrm{e}}$ siècle.

Danielle BUSCHINGER, La cour des ducs de Bourgogne et l'espace germanophone à la fin du Moyen Âge, pp. 177-194. C'est à partir de La littérature française à la cour des Ducs de Bourgogne de Georges Doutrepont (1909) que D.B. dresse l'inventaire des œuvres qui, présentes dans la bibliothèque des Ducs ou dans celle de Charles de Croÿ, ont été traduites en allemand au $\mathrm{xv}^{\mathrm{e}}$ siècle. Il s'agit de: Cleomadés en prose, Olivier de Castille et Artus d'Algarbe, Renaut de Montauban (adapté en allemand à partir d'une version néerlandaise), Fierabras, le Livre du Chevalier de la Tour-Landry, Melusine de Coudrette, Ponthus et Sidoine. Sont étudiées plus en particulier la traduction en alémanique du Livre des faits d'armes et de chevalerie de Christine de Pizan (dont il est pour l'instant impossible de reconnaître le manuscrit source) et celle de Pierre de Provence et la belle Maguelonne (basée sur le célèbre manuscrit de Cobourg). Ce panoramique montre bien que la Suisse - et la ville de Berne en particulier, où la plupart des traductions furent exécutées -, bien qu'opposée à la Bourgogne sur le plan politique, en subit néanmoins à l'époque des Ducs Valois l'influence culturelle et littéraire.

3 Nadine HENRARD, Le "Roman en prose de Guillaume d'Orange" et le monde bourguignon, pp. 195-207. De nombreux éléments permettent de rattacher le Guillaume d'Orange en prose au milieu bourguignon; il s'agit tant d'indices externes (la facture des deux manuscrits) que de 'traces' internes au texte: des ajouts ne figurant pas dans la source en vers, le rapprochement avec d'autres textes 'bourguignons' (notamment les Cronicques et Conquestes de Charlemaine de David Aubert), des références explicites à la Bourgogne, une vision valorisante des sujets du Duché. D’autres éléments, moins sûrs à mes yeux 
(tels une probable allusion au Banquet du Faisan), permettraient de resserrer la datation du texte entre 1454 et 1456 (date du second volume des Cronicques de David Aubert).

4 Alexandre WINKLER, Le Cycle de la Croisade à la cour de Bourgogne, pp. 229-241. Tout en constatant la pauvreté de la 'librairie' des ducs de Bourgogne quant aux épopées strictement liées à la Croisade, notamment pour les chansons de geste du 'Premier cycle', A.W. relève une présence diffuse du motif dans des textes romanesques composés à l'intention des ducs voire circulant en milieu bourguignon: il rappelle notamment Bandouin de Flandres, la Belle Hélène de Constantinople en vers (sans citer les deux remaniements en prose: l'un anonyme, l'autre de Jean Wauquelin et commandité par Philippe le Bon lui-même), Gillion de Trazegnies, la Fille du comte de Pontieu (là encore, en passant sous silence Jehan d'Avennes, dont le protagoniste participe à une Croisade en Espagne, et surtout Saladin, sorte de biographie chevaleresque du sultan, adaptation en prose de la chanson de geste qui achevait le 'Deuxième cycle'). 